\title{
Hydrology and Sedimentation of Bixler Run Basin, Central Pennsylvania
}

GEOLOGICAL SURVEY WATER-SUPPLY PAPER 1798-N

Prepared in cooperation with the

Pennsylvania Department of

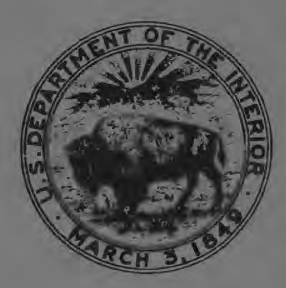

Environmental Resources,

State Conservation Commission 


\section{Hydrology and Sedimentation}

of Bixler Run Basin,

Central Pennsylvania

By LLOYD A. REED

SEDIMENTATION IN SMALL DRAINAGE RASINS

GEOLOGICAL SURVEY WATER-SUPPLI PAPER 1798-N

Prepared in cooperation with the

Pennsylvania Department of

Environmental Resources,

State Conservation Commission

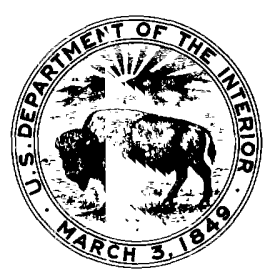




\section{UNITED STATES DEPARTMENT OF THE INTERIOR}

THOMAS S. KLEPPE, Secretary

\section{GEOLOGICAL SURVEY}

V. E. McKelvey, Director

Library of Congress Cataloging in Publication Data

Reed, Lloyd A

Hydrology and sedimentation of Bixler Run Basin, central Pennsylvania.

(Sedimentation in small drainage basins) (Geological Survey water-supply paper; 1798-N)

Bibliography: $p$.

Supt. of Docs. No.: I 19.13:1798-N

1. Hydrology-Pennsylvania-Bixler Run watershed. 2. Sediment transport-Pennsylvania-Bixler Run watershed. I. Pennsylvania. State Conservation Commission. II. Title. III. Series. IV. Series: United States. Geological Survey Water-supply paper ; $1798-\mathrm{N}$.

TC801.U2 no. 1798-N [GB705P4] 627'.08s

$\left[551.4^{\prime} 8^{\prime} 0974845\right] \quad 75-619263$

For sale by the Superintendent of Documents, U.S. Government F •inting Office Washington, D.C. 20402

Stock Number 024-001027-59-3 


\section{CONTENTS}

$\begin{array}{lr}\text { Mage } & \text { Petric-English equivalents } \\ \text { V }\end{array}$

Abstract _.

Introduction _... 1

The basin _... 2

Topography _... 2

Geology

Agriculture -

Conservation measures

Hydrology - _.- 6

Precipitation -

Streamflow _.

Sediment yields _._. 9

Suspended-sediment concentrations _..... 10

Size of suspended sediments _... 11

Stream channel changes _._. 12

Water chemistry _... 14

Summary and conclusions _.... 15

Selected references _._.

\section{ILLUSTRATIONS}

Figure 1. Map showing location of Bixler Run basin and data-cnllection sites

2-7. Graphs showing:

2. Variations in monthly precipitation, Bixler Run basin, June 1954 to September 1969

3. Duration curve of mean daily water discharge, Bixler Run near Loysville, October 1954 to September 1969

Page

N3

4. Double-mass comparison of annual rainfall and runoff, Bixler Run near Loysville, February 1954 to September 1969

5. Double-mass comparison of annual water and sediment discharge, Bixler Run near Loysville, February 1954 to September 1969

6. Duration curve of mean daily sediment concentration, Bixler Run near Loysville, Octol er 1954 to September 1969

7. Relation between stream discharge and concentration of sand-sized particles suspended in the flow 
$\begin{array}{lll}\text { Figure } & \text { 8. Channel cross sections at ranges } 1 \text { and } 12,1954 \text { and } 1964 \\ & 9 . & \text { Photograph showing actively scouring right back t range }\end{array}$

Page N14 10, near Kistler

10. Channel cross sections at range 10 near Kistler, showing channel realinement, 1954 and 1963

11. Series of photographs showing channel work and subsequent realinement, Bixler Run near Kistler

\section{TABLES}

TABLE 1. Conservation measures and land use in the Bixler Run basin

Page

2. Summary of hydrologic data, Bixler Run near Loysville, 1954-69

3. Chemical analyses of water, Bixler Run near Loysville, 1957-69 


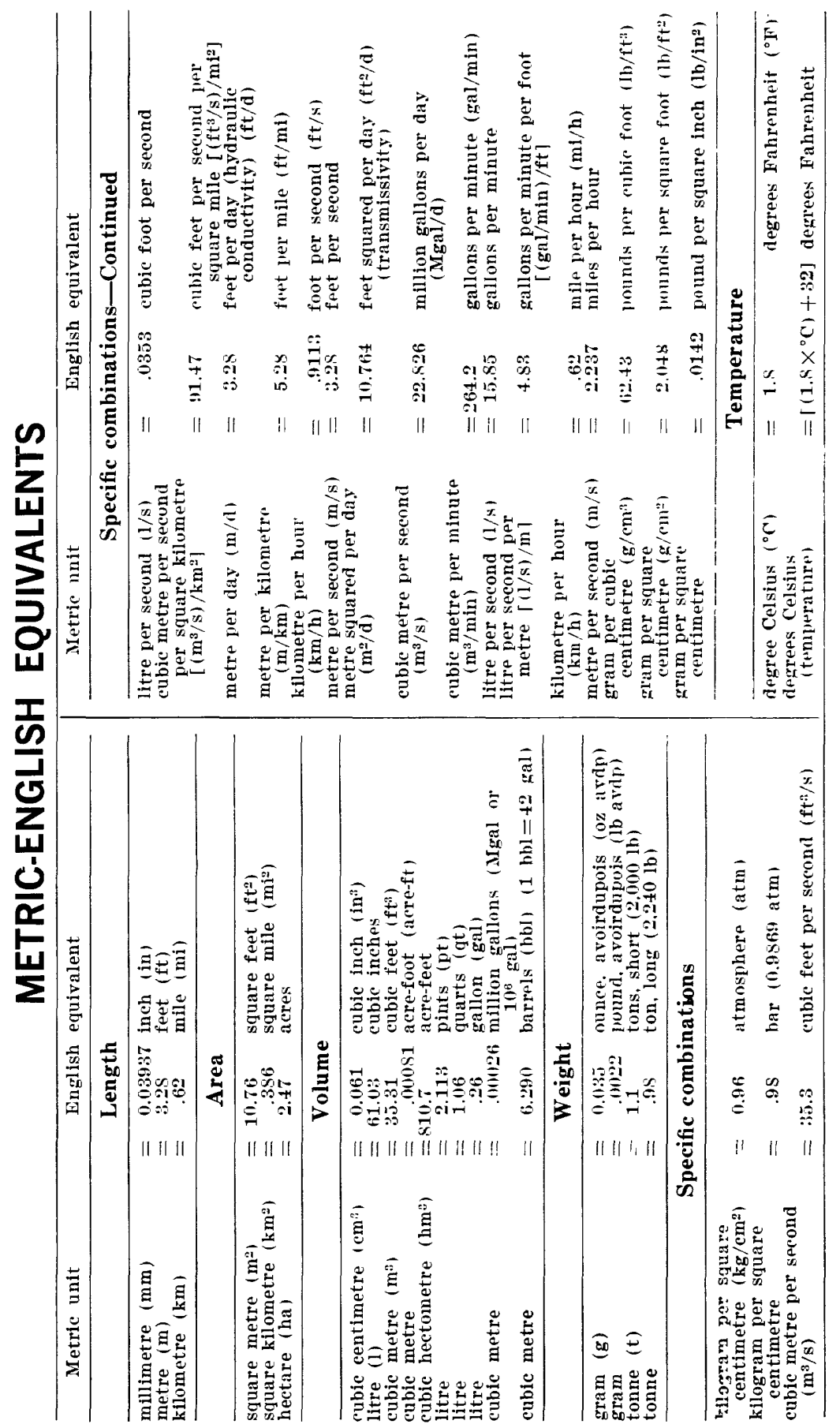




\title{
HYDROLOGY AND SEDIMENTATION OF BIXLER RUN BASIN, CENTRAL PENNSYLVANIA
}

\author{
By LLOYd A. REED
}

\begin{abstract}
Rainfall, streamflow, stream chemical, and sediment discharge data were collected from Bixler Run near Loysville, Pa., during the period from February 1954 to September 1969 as part of a project to evaluate sediment discharge from an agricultural area in which soil-conservation techniques were being adopted at a moderate rate. The study was conducted by the U.S. Geological Survey in cooperation with the Pennsylvania Department of Environmental Resources, State Conservation Commission.

Sediment yields from the basin averaged 64 tons per square mile ( 22 tonnes per square kilometre) per year, approximately 25 percent less than yields from the surrounding area. The relation between water discharge and suspended-sediment discharge remained constant during the study. Suspendedsediment concentrations in the streamflow were less than 10 milligrams per litre 70 percent of the time. The concentration of chloride ions in the streamflow increased from 1959 to 1969 . Ground water maintained flows at the gaging location at a rate of 1.9 cubic feet per second $(0.054$ cubic metres per second) during the period of data collection.
\end{abstract}

\section{INTRODUCTION}

The Pennsylvania Department of Environmental Resources, State Conservation Commission, and the U.S. Geological Survey entered into an agreement during November 1953 that provided for the collection of data to determine the amount of suspended sediment discharged by the stream draining the Bixler Run basin. The purpose of the study was to find the rate that sediment was being discharged and to determine if soil-conservation measures that have been adopted by farmers in the basin reduced the rate of sediment discharge. The data-collection program provided for collecting samples of the streamflow for suspended-sediment con- 
centration analysis, continuous monitoring of streamf'ow, and the measuring of precipitation. Samples of the streamflow were also collected periodically and analyzed for chemical constituents.

Bixler Run basin was chosen for the investigation of sediment discharge because it was typical of the many general-farming areas in central Pennsylvania where soil-conservation programs were being adopted. Permanent agricultural conserration practices were first applied to areas in the basin as early as the 1930's.

The data have been collected by the U.S. Geological Survey with the assistance of many local observers. This report presents an analysis of the sediment and related data collected during the period from April 1954 to September 1969 as well as a description of the soil-conservation program.

An investigation of the rate of suspended-sediment discharge from drainage basins with agriculture as the major land use was also conducted on Corey Creek and Elk Run basins, in northcentral Pennsylvania, from 1954 to 1967. The rate of sediment discharge from the Bixler Run basin was described by Culbertson (1957) in a report that also included the Corey Creek and Elk Run basins of north-central Pennsylvania. Jones (1966) and Reed (1971) presented a more detailed analysis of the sodiment discharge and hydrology of Corey Creek and Elk Run using data collected from 1954 through 1960 and 1954 through 1967, respectively.

Generalized sediment yields from streams in the Susquehanna River basin, of which Bixler Run basin is a part, were reported by Williams and George (1968) and by Williams and Peed (1972).

\section{THE BASIN}

Bixler Run basin (fig. 1) is in the Valley and Ridge province of central Pennsylvania, approximately $30 \mathrm{mi}(48 \mathrm{~km})$ west of Harrisburg. The basin drains an area of $15 \mathrm{mi}^{2}\left(39 \mathrm{~km}^{2}\right)$ from the top of Conococheague Mountain in the northwest to the stream-gaging station $3 \mathrm{mi}(5 \mathrm{~km})$ west of Loysville. Two small villages, Kistler and Pine Grove, are near the center of the basin.

\section{TOPOGRAPHY}

Land-surface altitúdes in the Bixler Run basin range from about $2,000 \mathrm{ft}(600 \mathrm{~m})$ on Conococheague Mountain to $600 \mathrm{ft}$ $(180 \mathrm{~m})$ at the stream gage. The valley floor at Kistler is $670 \mathrm{ft}$ $(205 \mathrm{~m})$ above sea level. The mean altitude of the ertire basin is $870 \mathrm{ft}(265 \mathrm{~m})$. 


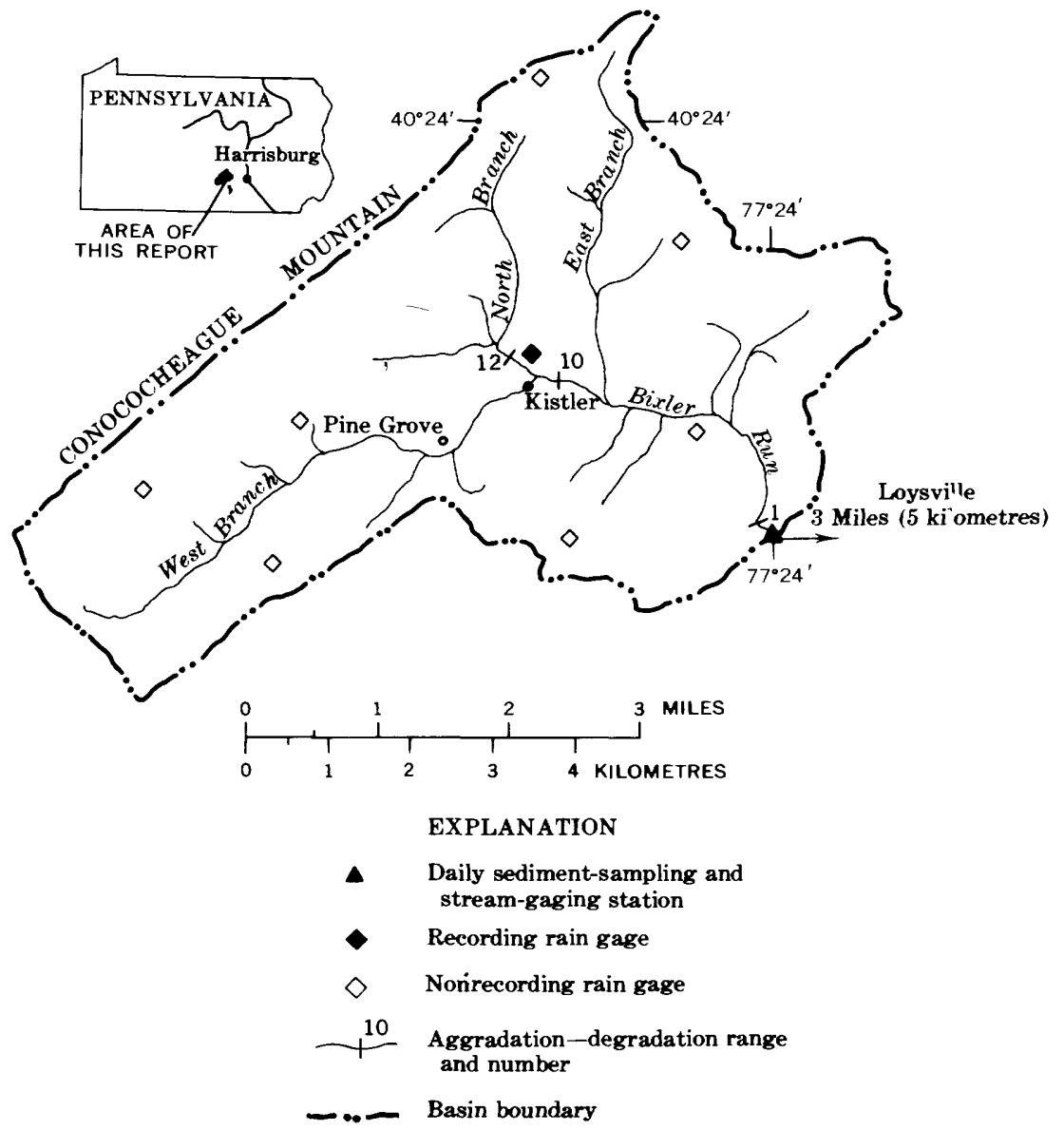

Figure 1.-Location of Bixler Run basin and data-collection sites.

Slopes range from about 45 percent on the face of the mountain to nearly flat in parts of the valley. Sixty percent of the basin has slopes greater than 10 percent, and the mean basin slope is 11 percent. The topography is typical of that found in most of the Valley and Ridge province of the State.

\section{GEOLOGY}

The headwaters of Bixler Run originate on Conococheague Mountain in the quartzitic sandstone of the Tuscarora Formetion of Silurian age. The lower part of the mountain is underlain ky limestone, siltstone, shale, and sandstone of the Rose Hill and Mifflintown Formations of Silurian age. Forests cover most of the mountains; however, agriculture is practiced on parts of the lower slopes. 
The majority of the basin lowlands are underlain by limestone and shale belonging to the Wills Creek Formation of Silurian age. Steep slopes in the lowlands are forested, but nearly all the flat and moderate slopes are used for crop production or farmsteads. A part of the southeast end of the basin is underlain by sandstone of Middle Devonian age and is principally forested. T'ere are no major faults or folds in the basin.

About 8 percent of the basin is underlain by quartzitic sandstone, 22 percent by sandy shale, 54 percent by calcareous shale, and 16 percent by sandstone.

\section{AGRICULTURE}

Although lumber and pulpwood are harvested periodically, agriculture (mostly dairy farming) is the principal economic activity in the basin. The chief crops are corn, hay, oats, and wheat. Corn is grown for ensilage and grain. The hay crops include alfalfa, which is a permanent perennial crop, and timothy and clover, which are usually harvested for only one season. Corn may be grown in the same field for 2 years. The field then is sown to oats in the spring of the third year. The oats are harvested in July, and the plot is seeded to wheat in the fall. Wheat is normally the companion crop to timothy and clover. The wheat is hervested the next summer, and the first crop of hay is harvested the following spring. The time span from hay to hay is $\mathbf{5}$ years if corn is grown for two seasons.

\section{CONSERVATION MEASURES}

Soil-conservation measures are being applied to the basin at a moderate rate. The most easily measured key to the quantity of conservation practiced is the ratio of the number of acres of contour and regular strip cropping to the number of farmed acres. Contour strips differ in width and have borders of ccnstant altitude; regular strips have the same widths and have borders parallel to fence rows or roads. Total land in strip crops, table 1, increased from 1,000 acres $\left(400 \mathrm{hm}^{2}\right)$ in 1949 to 1,810 acres $(730$ $\mathrm{hm}^{2}$ ) in 1970, an increase from 10.4 to 18.7 percent of the basin. Farms are not usually converted entirely to strip cropping, as it is not required on areas that are flat, permanently planted with hay (alfalfa), or permanently used for pasture. Cortour strips were first used in the basin in the 1930's and have boen gaining in popularity since. Many other soil- and water-conser"ation techniques are associated with the introduction of strip crops, such as diversion terraces that route water around hillsides and controlled outlet structures that route the collected water to streams. The 


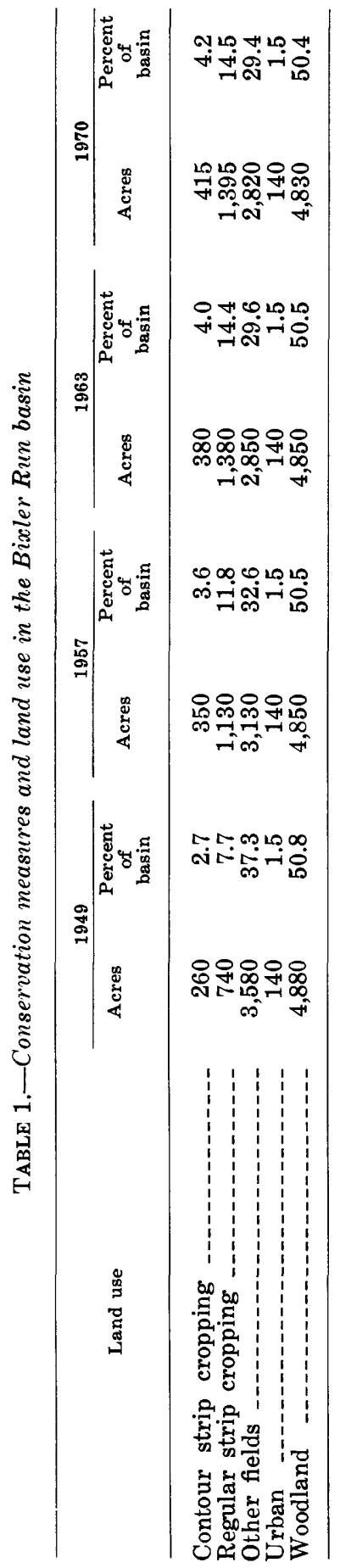


area in woodland remained relatively constant at a.bout 4,850 acres $\left(1,960 \mathrm{hm}^{2}\right)$ or just more than 50 percent of the basin. Some small areas have been allowed to return to woodland, and other wooded areas have been cleared. The urban area remained constant at about 1.5 percent of the basin.

\section{HYDROLOGY}

Rainfall, streamflow, and sediment data were collected by personnel of the U.S. Geological Survey and local observers at locations indicated in figure 1. The data-collection program was initiated in the spring of 1954. All of the data collected were analyzed on the basis of water years which run from Otober 1 to September 30, and are designated by the calendar years in which they end.

\section{PRECIPITATION}

Precipitation data were collected at eight locations in the basin. The yearly averages for the basin were determined by averaging the yearly values for all locations. Average precipitation for the 15-year period was 41.8 in $(1,060 \mathrm{~mm})$ per year or 3.48 in (88 $\mathrm{mm})$ per month. Yearly precipitation ranged from 31.6 in (803 $\mathrm{mm})$ in the 1969 water year to 50.9 in $(1,290 \mathrm{~mm})$ during the 1960 water year. Table 2 shows the yearly rainfall ard other hydrologic data collected from the basin. The maximum monthly precipitation of 12.7 in $(323 \mathrm{~mm})$ occurred in August $1955 ; 5.5$ in $(140 \mathrm{~mm})$ of this was associated with the passage of Hurricane Diane during the middle of the month. The minimum monthly precipitation occurred during October 1963 when 0.11 in (2.8 $\mathrm{mm}$ ) of precipitation was recorded in the basin. The mean monthly precipitation was highest in October and April ard lowest in January, May, and September. Figure 2 is a bar graph showing the basin average, monthly maximum, mean, and minimum precipitation, and the mean monthly precipitation for the 15-year period.

\section{STEAMFLOW}

Streamflow has been recorded at the gage on Bixler Run, approximately $4 \mathrm{mi}(6 \mathrm{~km})$ west of Loysville and $2 \mathrm{mi}(3 \mathrm{~km})$ south of Kistler, since February 1954. The minimum daily flow observed at the gage was $1.9 \mathrm{ft}^{3} / \mathrm{s}\left(0.054 \mathrm{~m}^{3} / \mathrm{s}\right)$. The minimum flow occurred for 7 days during a 12-day period in September 1966 after only 4 in $(100 \mathrm{~mm})$ of precipitation had fallen during: June, July, and August. Maximum instantaneous discharge fror the basin, 


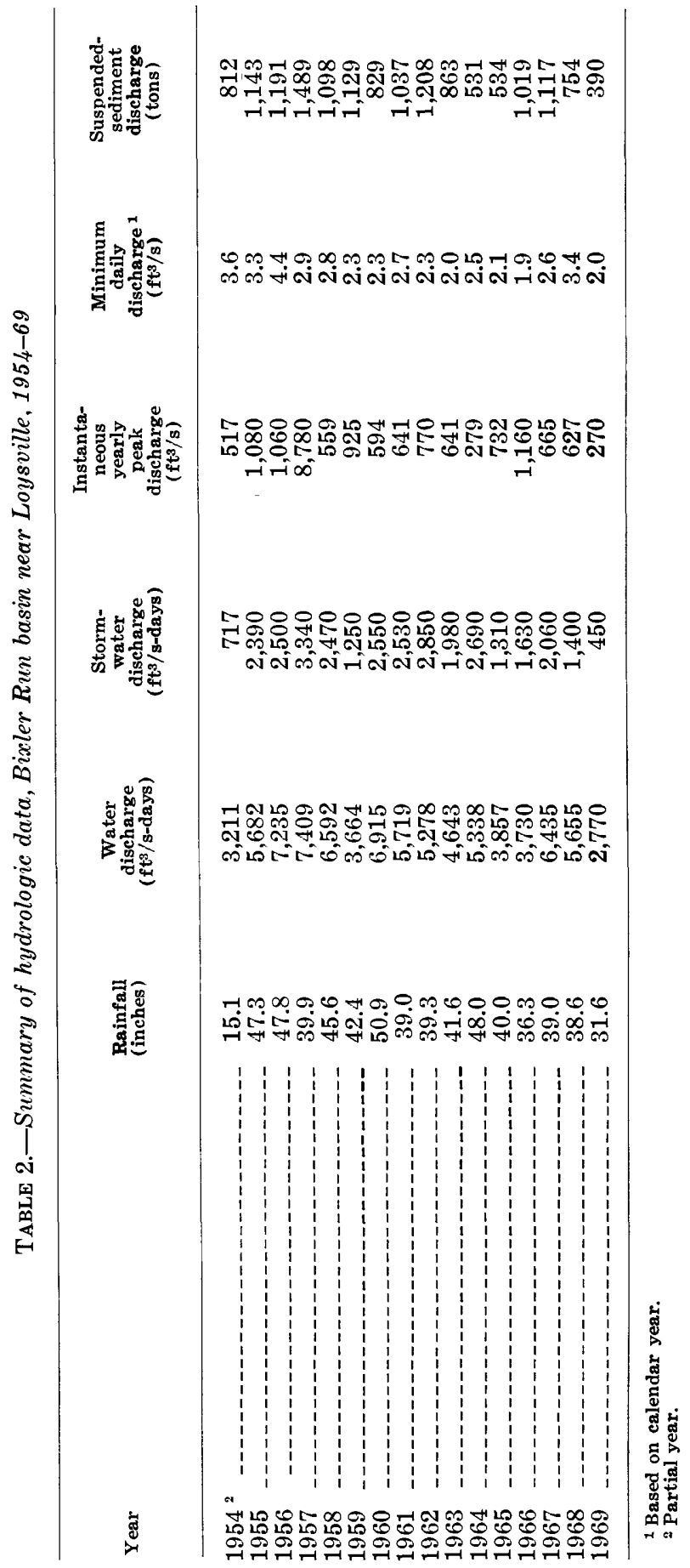




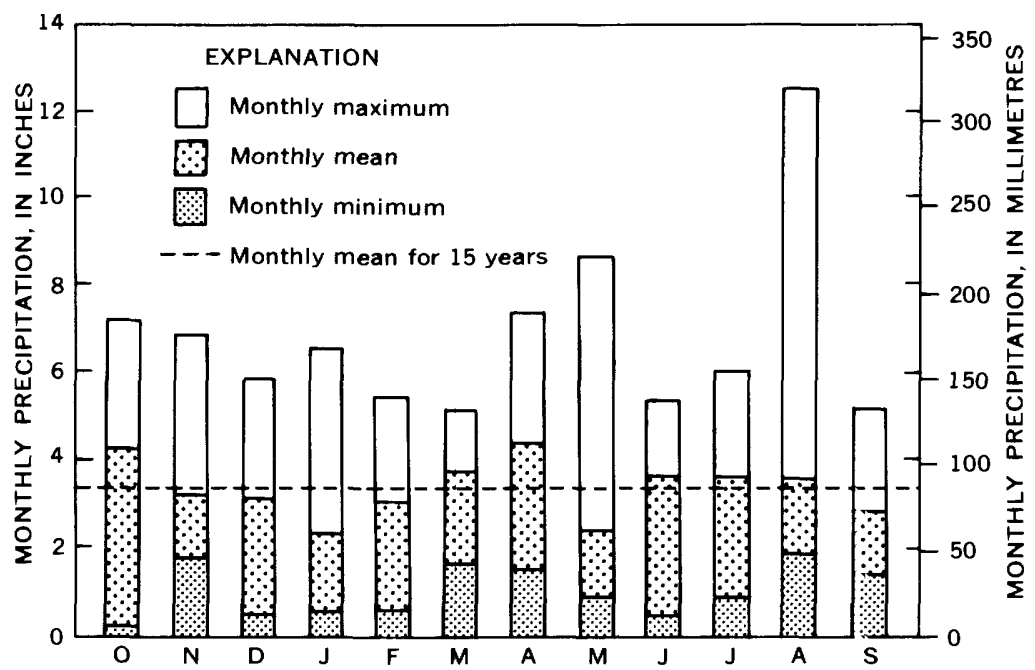

Figure 2.-Variations in monthly precipitation, Bixler Run basin, June 1954 to September 1969.

$8,780 \mathrm{ft}^{3} / \mathrm{s}\left(250 \mathrm{~m}^{3} / \mathrm{s}\right)$, occurred on November 1,1955 , when 4.05 in $(103 \mathrm{~mm})$ of precipitation fell, 2.6 in $(66 \mathrm{~mm})$ of it in a $45-$ minute period. This was preceded by 4 in $(100 \mathrm{~mm})$ of precipitation in the 10 days prior to November 1 .

Figure 3 shows the flow duration curve for Bixler Run basin based on 15 years of record. Flow from Bixler Run was sustained at or above $1.9 \mathrm{ft}^{3} / \mathrm{s}\left(0.054 \mathrm{~m}^{3} / \mathrm{s}\right) 99.9$ percent of the time. Johnston (1970) reported that the high minimum flow may be due to steep water table gradients and a high gravity yield for the zone of water-table fluctuation.

Figure 4 is a double-mass curve that shows the relation between annual runoff and precipitation. It shows that there was no change in the precipitation-runoff relation. During the 15 full years of data collection (1955-69), average-annual precipitation was 41.8 in $(1,060 \mathrm{~mm})$ and average-annual streamflow was $5,400 \mathrm{ft}^{3} / \mathrm{s}-$ days $\left(153 \mathrm{~m}^{3}\right.$ 's-days $)$ or 13.4 in $(340 \mathrm{~mm})$. For the period, 32 percent of the precipitation ended as streamflow; the remaining 68 percent provided moisture for vegetal growth or evaporated directly to the atmosphere,

Storm-water discharge was separated from the total recorded streamflow on a daily basis by assuming that when runoff occurred the increased water discharge was storm runoff. It was also assumed that the storm water was completely discharged within 3 days and that the stream had then returned to a high 


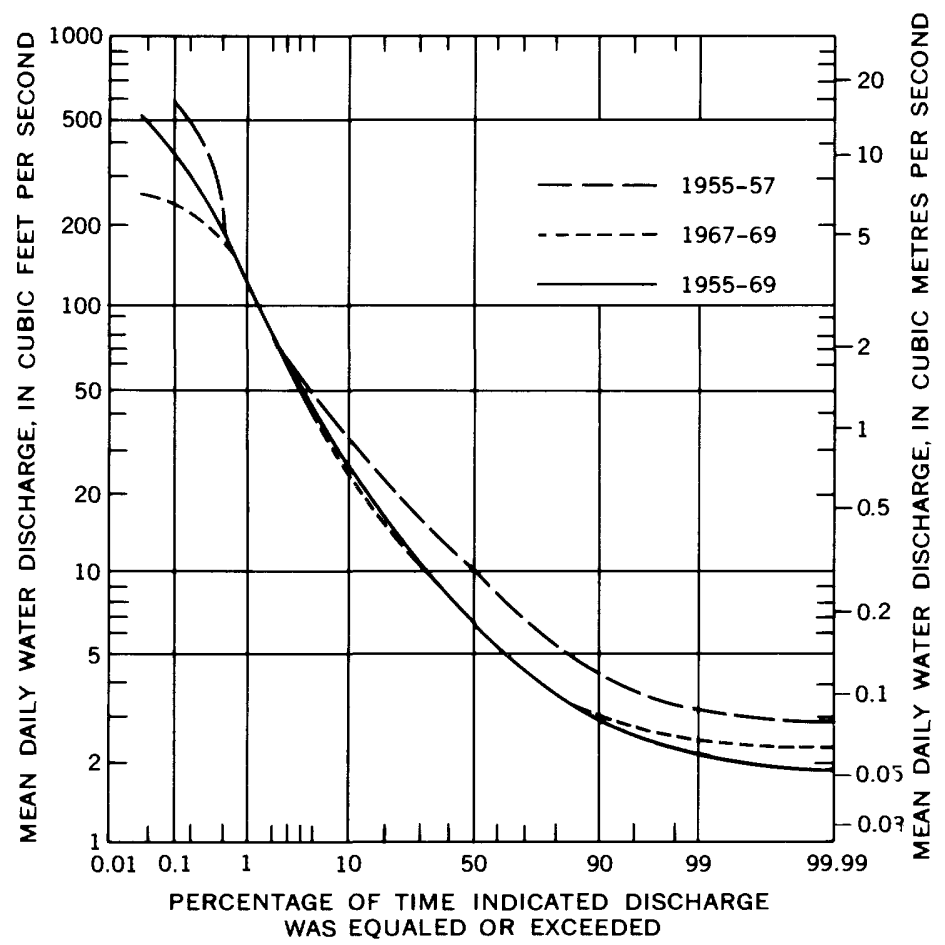

FIGURE 3.-Duration curve of mean daily water discharge, Bixler Run near Loysville, October 1954 to September 1969 .

level of base flow. Based on this analysis, 60 percent of th: 5,400 $\mathrm{ft}^{3} / \mathrm{s}$-days $\left(153 \mathrm{~m}^{3} / \mathrm{s}\right.$-days) of average annual streamflow vas base flow and an average of 40 percent was storm-water discherge.

\section{SEDIMENT YIELDS}

The collection of suspended-sediment discharge data was begun in February 1954 at the stream-gaging station. Suspenc'ed-sediment samples were collected by standard U.S. Geological Survey procedures, which include the use of depth-integrating samplers and automatic-sampling equipment.

During the full 15 years (1955-69) of data collection. 14,332 tons $(13,002 t)$ of suspended sediment was discharged by Bixler Run (table 2). The average annual yield was $64 \mathrm{t} / \mathrm{mi}^{2}\left(22 \mathrm{t} / \mathrm{km}^{2}\right)$. The yield is 25 percent less than the yield reported by Williams and Reed (1972) for the Shermans Creek basin, of wrich the Bixler Run basin is part. The soil-conservation measures tlat have been adopted are apparently limiting the amount of sediment available to the stream. 


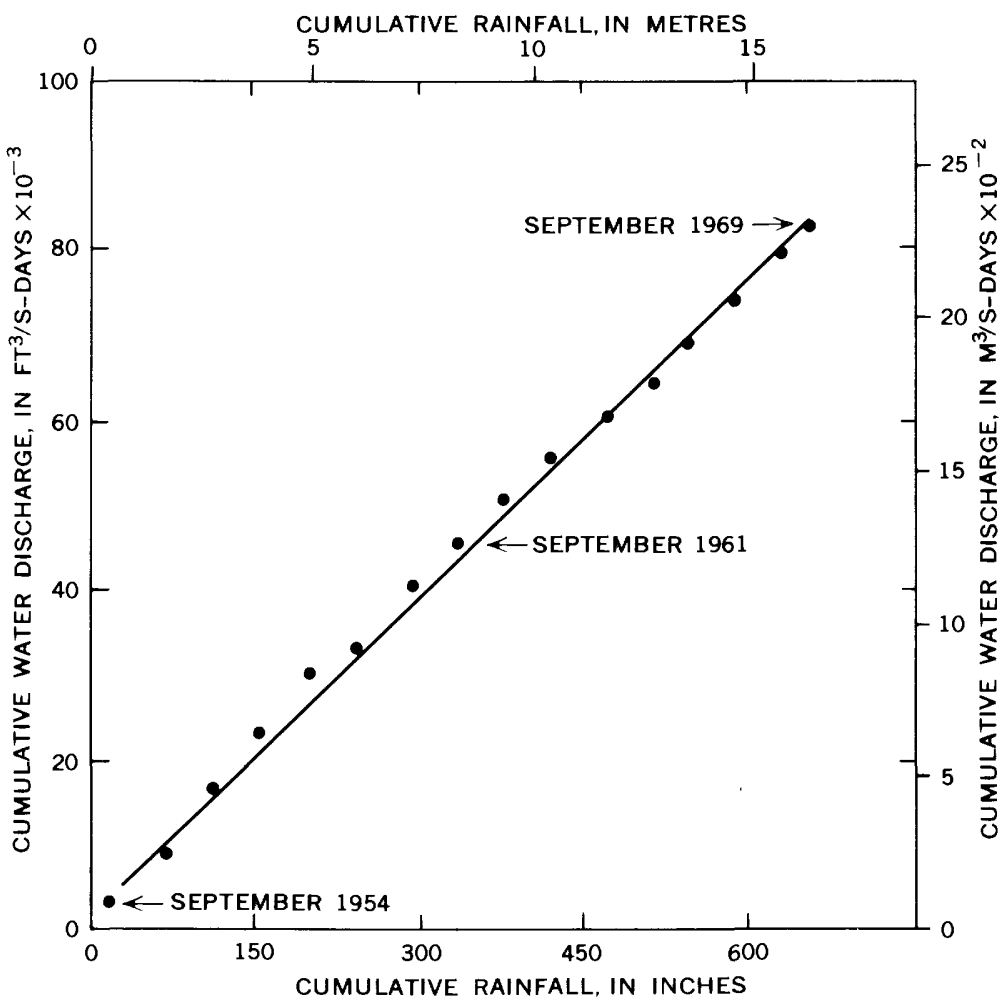

Figure 4.-Double-mass comparison of annual rainfall and runoff, Bixler Rur near Loysville, February 1954 to September 1969.

Using probable soil-loss data from Dumper anc Kirkaldie (1967) and a delivery ratio of $0.16 \mathrm{lb} / \mathrm{lb}(0.16 \mathrm{~kg} / \mathrm{kg})$, sediment yield was estimated to be $80 \mathrm{t} / \mathrm{mi}^{2}\left(30 \mathrm{t} / \mathrm{km}^{2}\right)$ per year, close to the measured values.

Figure 5 shows the double-mass relation between water and sediment discharge for Bixler Run for the period of the study. Although there were slight yearly variations, the long-term relation was stable, indicating that the rate of sediment discharge with respect to streamflow was constant.

\section{SUSPENDED-SEDIMENT CONCENTRATIONS}

Suspended-sediment concentrations observed in the stream during base-flow periods and periods of storm runoff did not change appreciably during the study. Figure 6 shows the susronded-sediment concentration duration curves for the first 3 years and last 3 years of the study, along with the curve that represents all 15 years of data. Variation between the three curves' is small; there- 


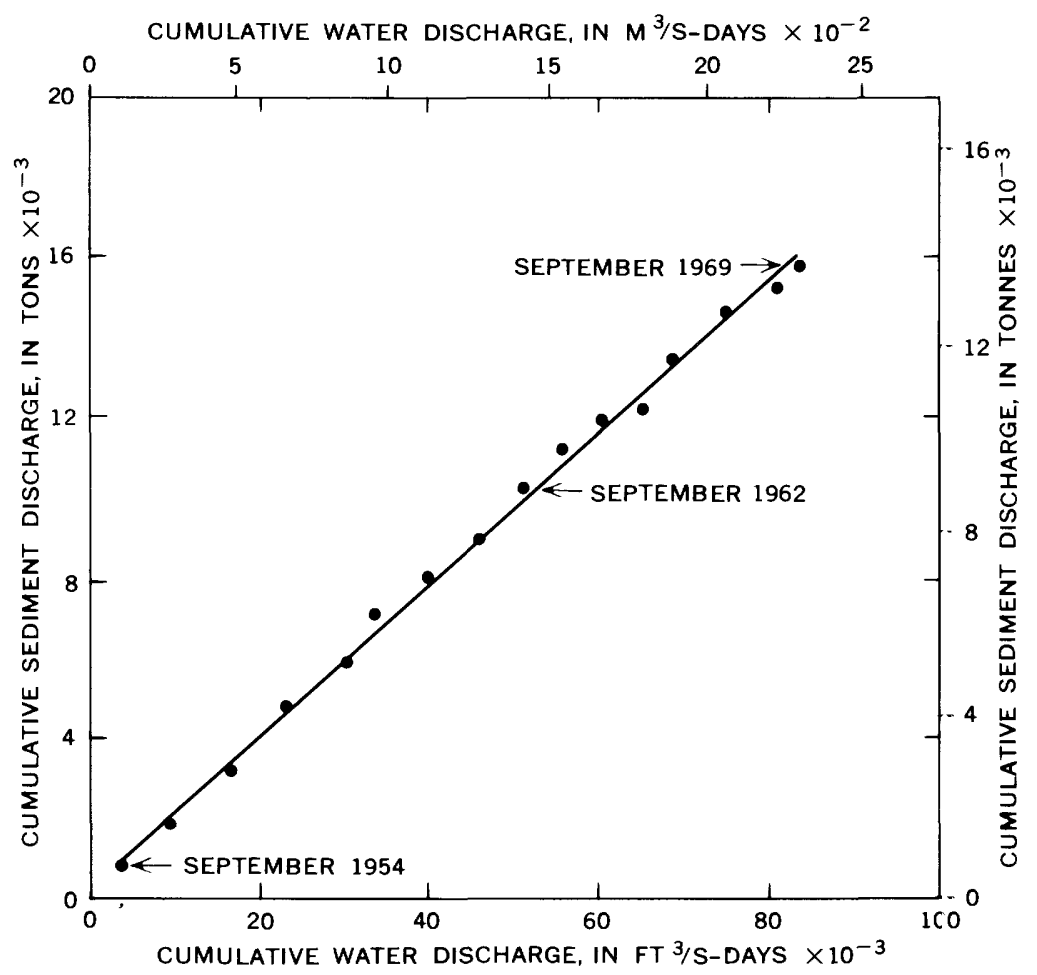

FIGURE 5.-Double-mass comparison of annual water and sediment discharge, Bixler Run near Loysville, February 1954 to September 1969.

fore, the frequency of occurrence of the suspended-sediment concentrations was fairly constant during the study. Figure 6 also shows that sediment concentrations in the streamflow were less than $10 \mathrm{mg} / 1$ (milligrams per litre), indicating a nearly sedimentfree streamflow approximately 70 percent of the time.

\section{SIZE OF SUSPENDED SEDIMENTS}

During the 15 years of data collection, 60 suspended-sediment samples were analyzed to determine the particle-size distribution. The samples were collected when suspended-sediment concentrations seemed to be greater than $100 \mathrm{mg} / \mathrm{l}$. Analysis of the size data revealed that during periods when the sediment concentration was greater than $100 \mathrm{mg} / \mathrm{l}$, silt and clay were the dominant sizes of the sediment being transported, each making up approximately 48 percent of the load. Little or no sand appeared to be transported until water discharge exceeded $40 \mathrm{ft}^{3} / \mathrm{s}\left(1.1 \mathrm{~m}^{3} / \mathrm{s}\right)$. Figure 7 shows the relation between water discharge and the concentration of suspended sand (particles larger than $0.062 \mathrm{~mm}$ but 


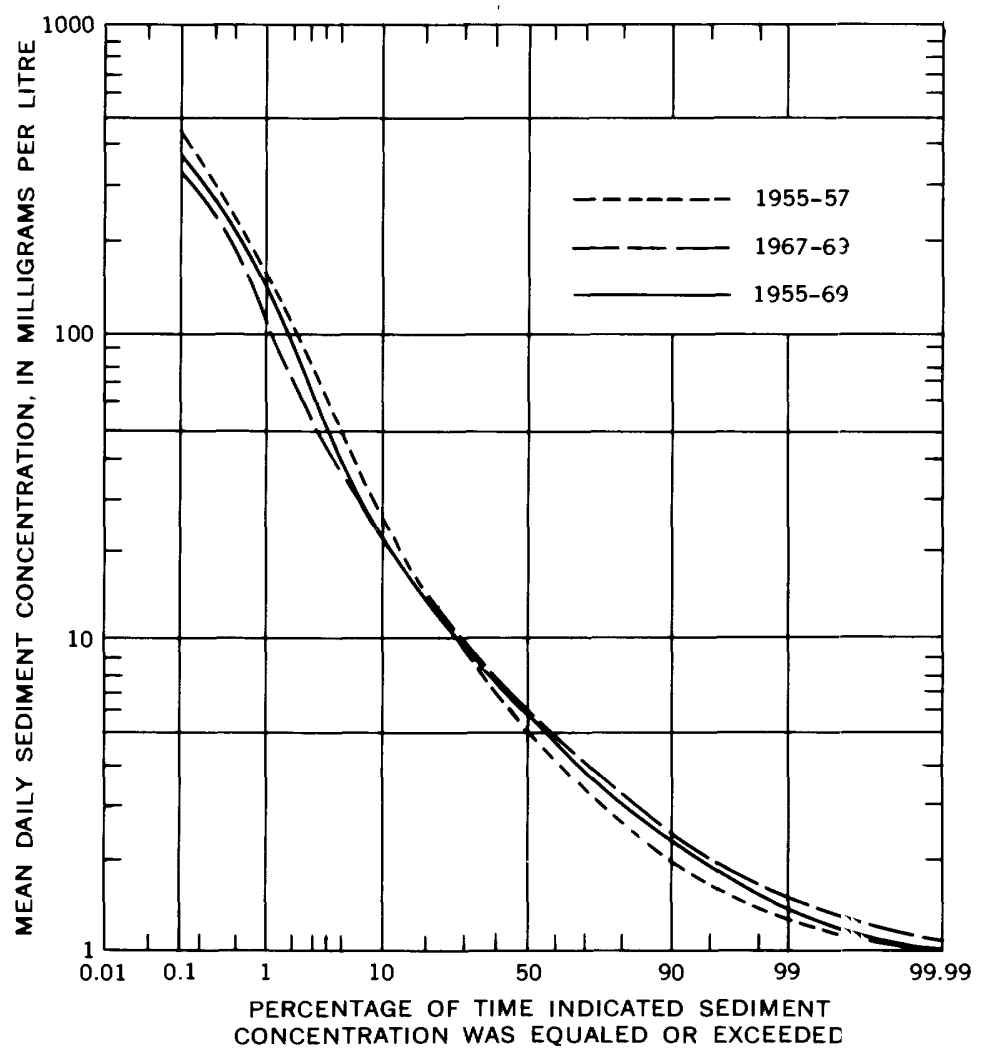

FrgURE 6.-Duration curve of mean daily sediment concentration, Bixler Rı'n near Loysville, October 1954 to September 1969.

small enough to enter the sampling nozzle which has a $6.35 \mathrm{~mm}$ diameter). The plot shows that sand concentration increased from approximately $2 \mathrm{mg} / \mathrm{l}$ at a flow of $40 \mathrm{ft}^{3} / \mathrm{s}\left(1.1 \mathrm{~m}^{3} / \mathrm{s}\right)$ to $60 \mathrm{mg} / \mathrm{l}$ at a flow of $900 \mathrm{ft}^{3} / \mathrm{s}\left(25 \mathrm{~m}^{3} / \mathrm{s}\right)$. An average annual discharge of 50 tons $(45 \mathrm{t}$ ) of suspended sand by Bixler Run at the gage was calculated by using the flow duration-sediment discharge method of computing annual sediment loads. Sand represented about 5 percent of the suspended-sediment load.

\section{STREAM CHANNEL CHANGES}

The channel of Bixler Run is in a state of stable alinement for most of its length. Figure 8 shows the surveyed cross sections of Bixler Run at two locations that are typical of the stability of the stream channel in most of the valley.

There are a few areas where channel realinement is taking place. One such area is a broad flood plain, underlain by uncon- 


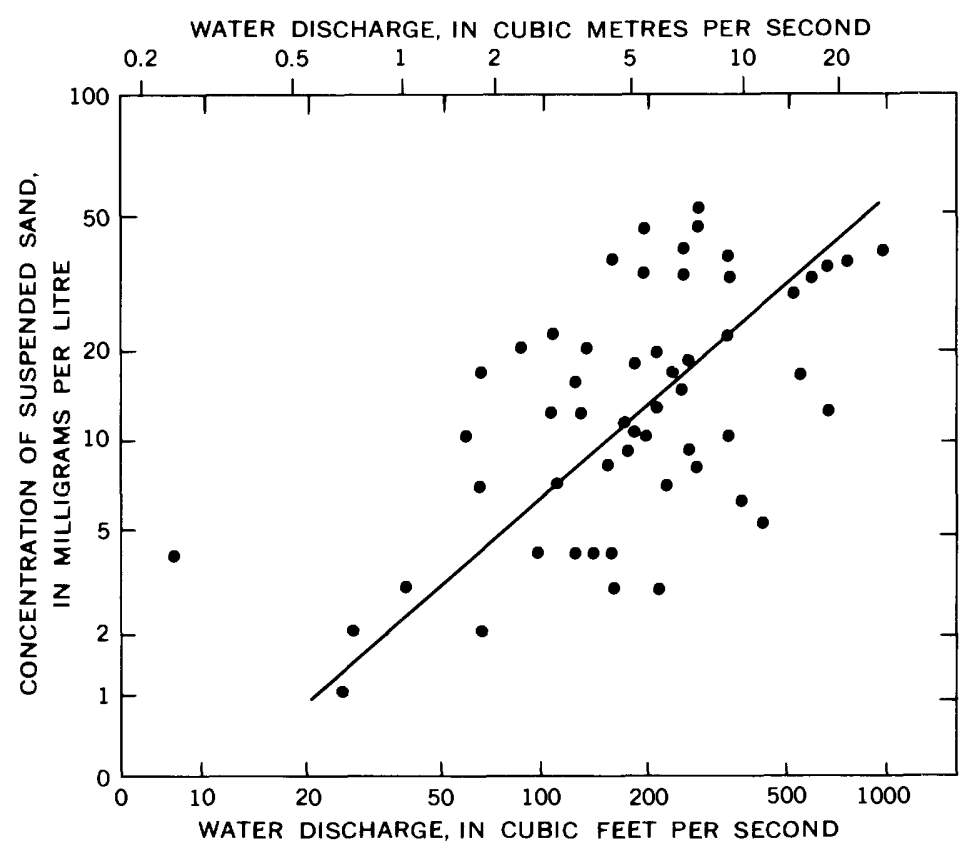

FIGURE 7.-Relation between stream discharge and concentration of sand-sized particles $(0.062$ $\mathrm{mm} \leq \mathrm{d} \leq 6.35 \mathrm{~mm}$ ) suspended in the flow.

solidated fill, just downstream from the village of Kistler in the area of range 10 . The channel length through this area is 1,200 ft $(370 \mathrm{~m})$ and the channel has an average slope of about 0.8 percent. Figure 9 is a photograph that was taken $50 \mathrm{ft}(15 \mathrm{~m})$ upstream from range 10 showing the right stream bank wlich is actively scouring.

Figure 10 is a channel cross section at range 10 which shows the net channel movement that took place from 1954 to $19 € 3$. The stream shifted an average of $2 \mathrm{ft}(0.6 \mathrm{~m})$ per year. Part of the shift was caused by the scouring action of high flow and frost action in the bank. Cattle are pastured in the area and their activity probably contributed to the bank scour.

Figure 11 is a series of three photographs, in time seouence, taken just downstream from Kistler at the confluence of the north and west branches. The photograph taken in January 1957 shows a section of the stream being cleared of gravel deposited during the November 1, 1956, flood. The photographs taken in 1959 and 1974 show the stream channel from about the same persrective. The degree of channel shifting can be appreciated by observing the large rock near the edge of the channel on the right side of 


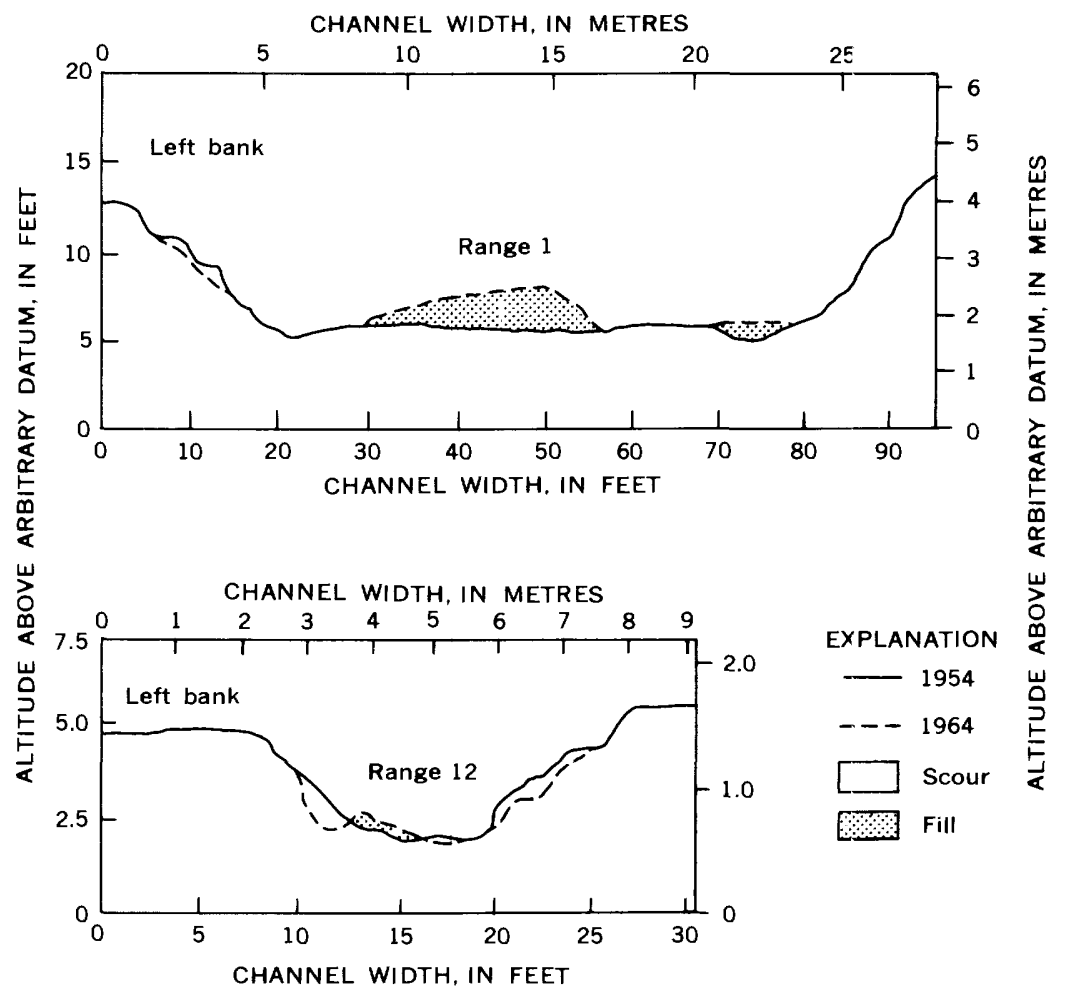

Figure 8.-Channel cross sections at ranges 1 and 12,1954 and 1964.

the 1957 photograph and in the middle of the 1969 and 1974 photographs.

Straightening of stream channels generally increases the stream slope, resulting in higher stream velocities and more active bank erosion immediately downstream. However, clearing the channel in January 1957 disturbed only about $100 \mathrm{ft}(30 \mathrm{~m})$ of the channel and probably did not affect the rate of bank scour in the area of range 10. Analysis of the surveyed cross sections of the Bixler Run channel indicated that gross erosion accounted for less than 10 percent of the sediment load measured at the gaging station near Loysville.

\section{WATER CHEMISTRY}

From 1957 to 1969,31 samples of water were analyzed for the common chemical elements (table 3). The data reveal that the concentrations of chloride ion increased almost steadily from 1957 to 1969 . The observed chloride ion concentrations averaged 2.4 


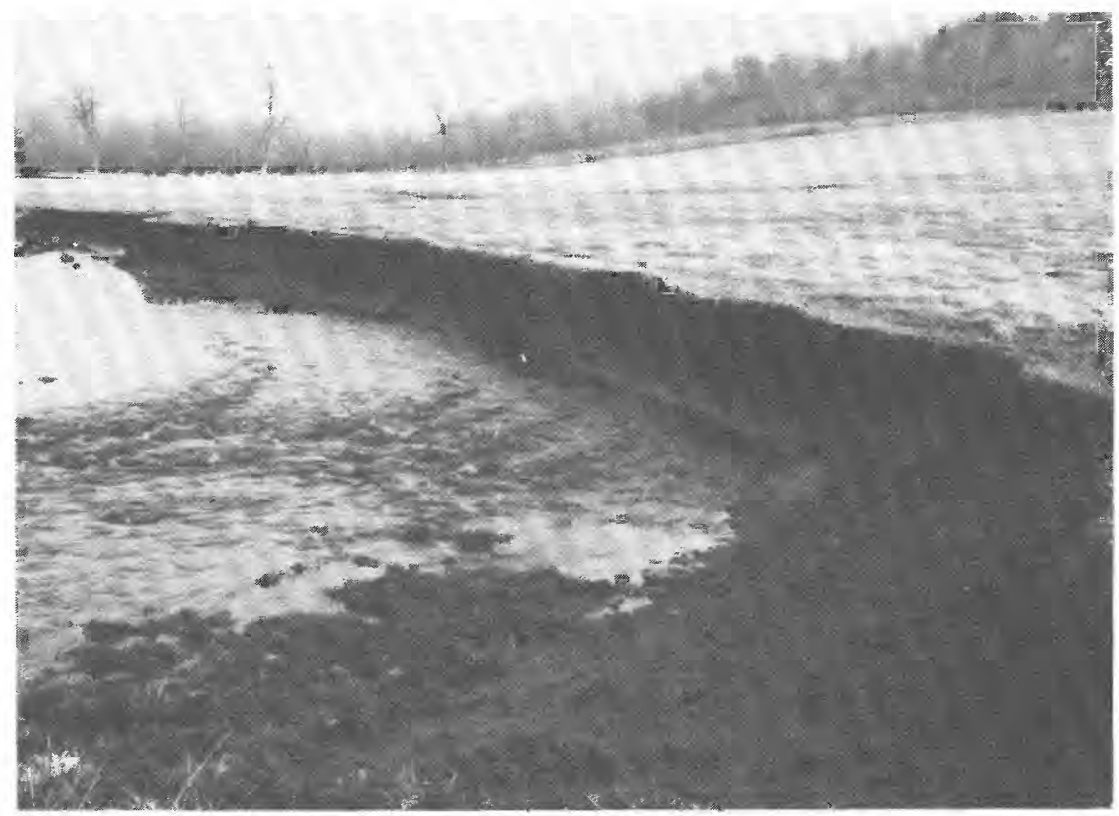

Figure 9.-Actively scouring right bank at range 10, near Kistler.

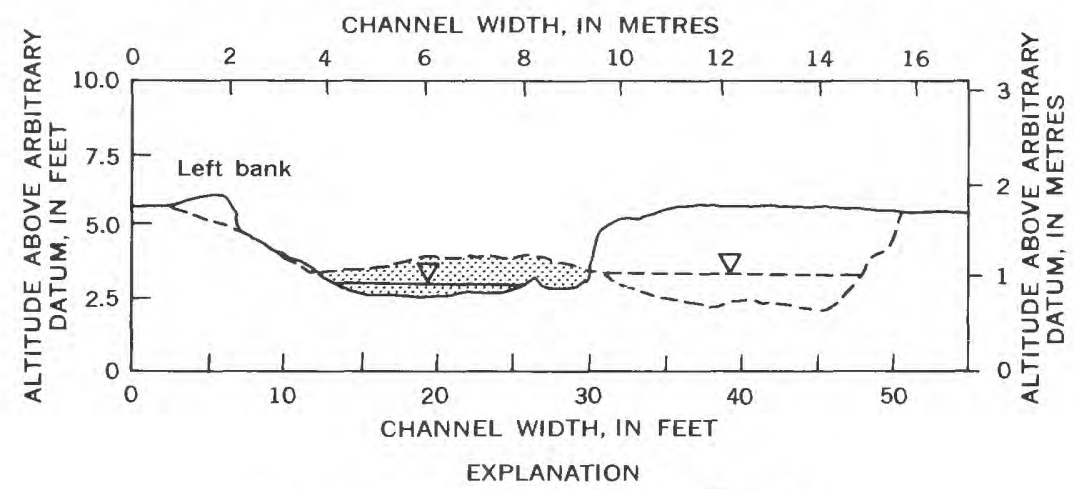

$-1954--1963 \square$ Fill $\square$ Scour
$\nabla$ Water surface

Figure 10.-Channel cross sections at range 10 near Kistler, showing channel realinement, 1954 and 1963.

$\mathrm{mg} / \mathrm{l}$ from 1957 to 1962 , and $4.4 \mathrm{mg} / \mathrm{l}$ from 1963 to 1967 . The increase probably is the result of the increased use of salts as melting agents on highways.

\section{SUMMARY AND CONCLUSIONS}

The application of conservation measures has been taking place at a moderate rate in the Bixler Run basin. The area in contour 


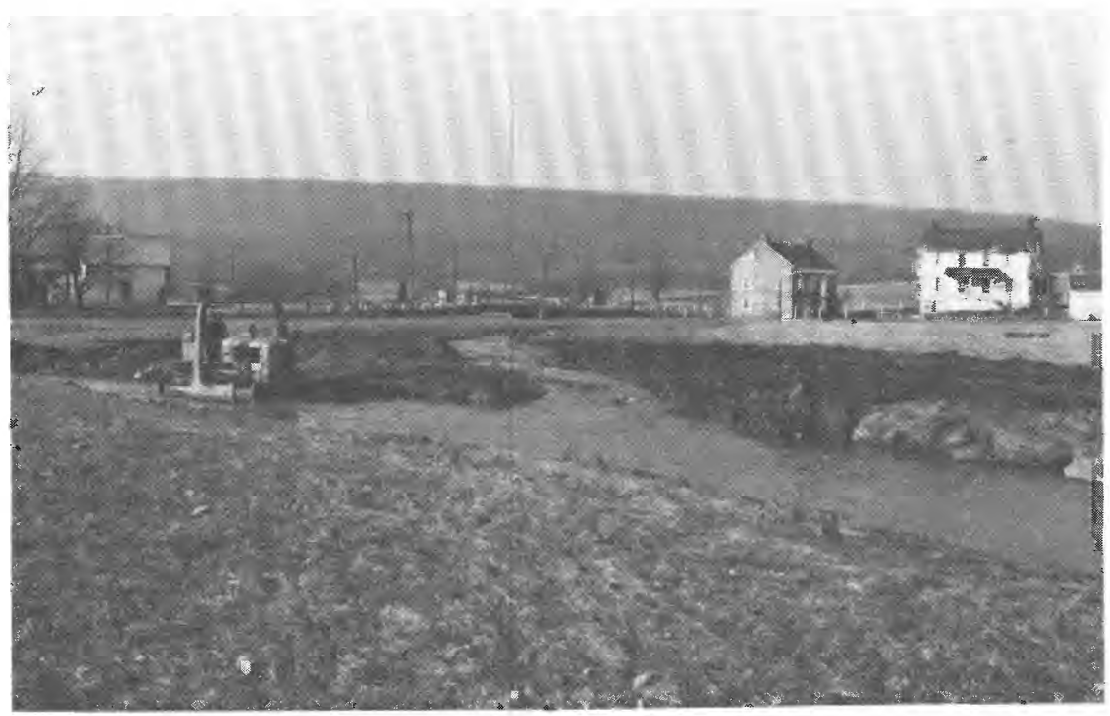

1957

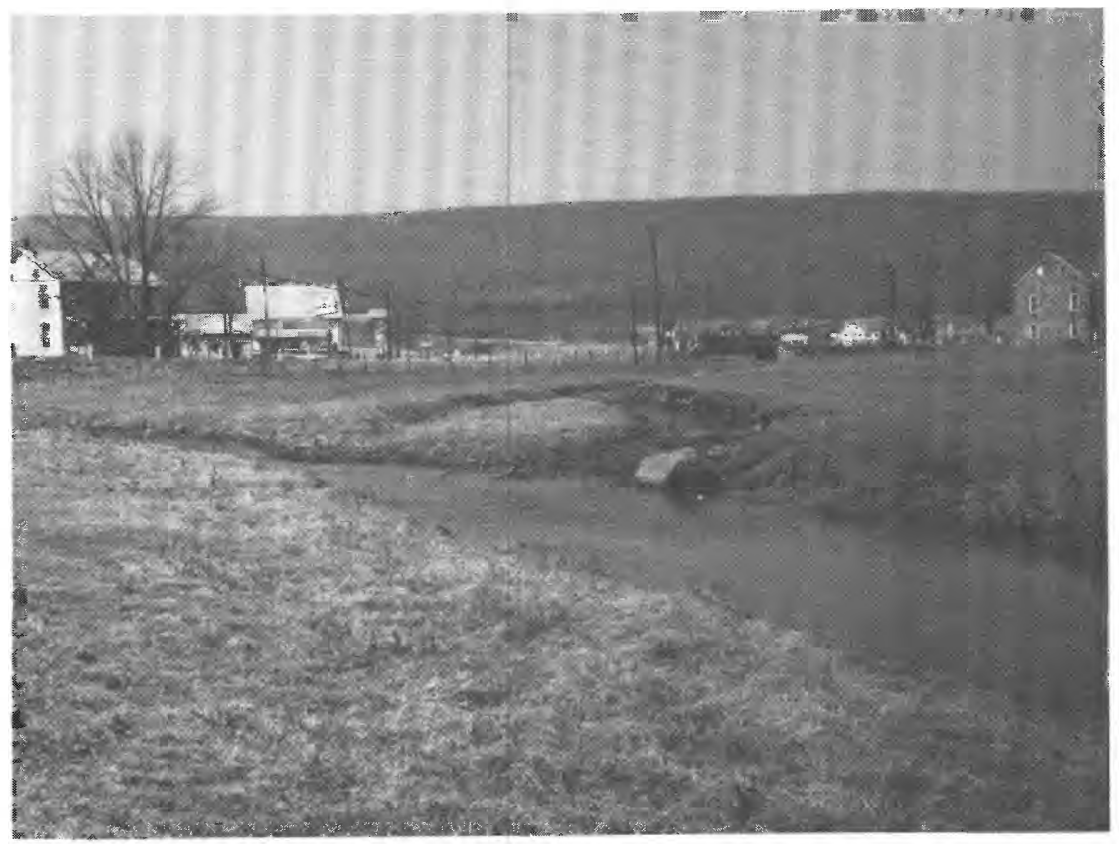

1969

FIGURE 11.-Channel work and subsequent realinement, Bixler Run near Kistler. 


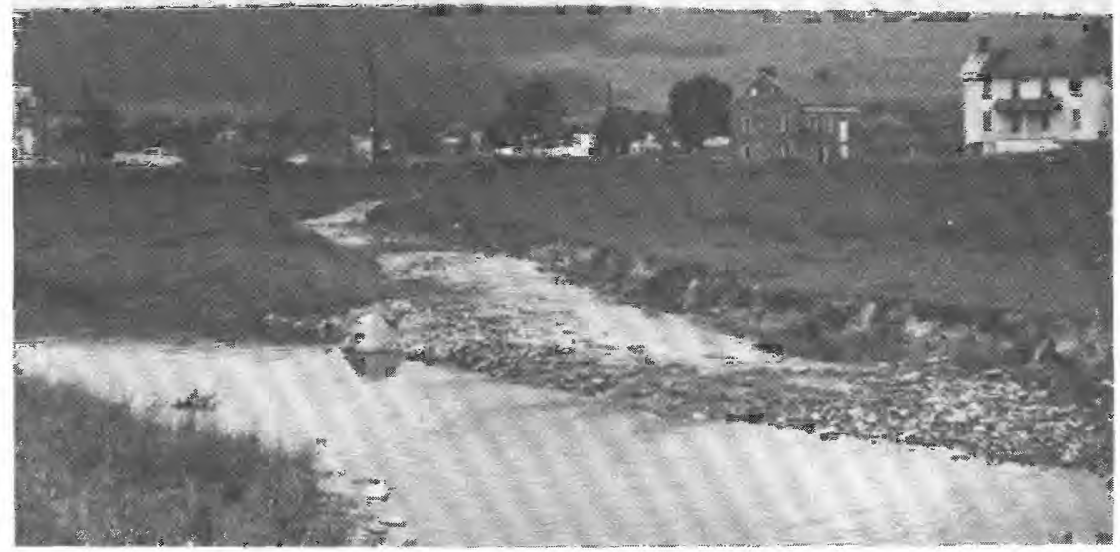

1974

Figure 11.-Continued.

and regular strip crops increased from 1,000 acres $\left(400 \mathrm{hm}^{2}\right)$ in 1949 to 1,810 acres $\left(730 \mathrm{hm}^{2}\right)$ in 1970 . The area in woodland remained constant, averaging 4,850 acres $\left(1,960 \mathrm{hm}^{2}\right)$.

Hydrologic data, including rainfall, streamflow, and sediment discharge, were collected from 1954 to 1969. Average-annual precipitation for the study period was 41.8 in $(1,060 \mathrm{~mm})$. October and April had the highest average monthly precipitation, and January and May had the lowest. Streamflow varied from a minimum flow of $1.9 \mathrm{ft}^{3} / \mathrm{s}\left(0.054 \mathrm{~m}^{3} / \mathrm{s}\right)$ to a maximum instantaneous flow of $8,780 \mathrm{ft}^{3} / \mathrm{s}\left(250 \mathrm{~m}^{3} / \mathrm{s}\right)$. Ground water sustained streamflow above $1.9 \mathrm{ft}^{3} / \mathrm{s}\left(0.054 \mathrm{~m}^{3} / \mathrm{s}\right)$. There was little change in the relation between rainfall and runoff during this investigation. Thirty-two percent of the precipitation was discharged from the basin as streamflow and 68 percent was lost to evapotranspiration. Of the streamflow, 60 percent was base flow and 40 percent was storm-water discharge.

During the 15 years (1955-69) of the study, 14,332 tons $(13,002 t)$ of sediment were discharged by Bixler Run-an average annual yield of $64 \mathrm{t} / \mathrm{mi}^{2}\left(22 \mathrm{t} / \mathrm{km}^{2}\right)$ per year. The low average annual sediment yields can be attributed to the soil conservation measures limiting the amount of sediment available to the stream. Bixler Run has sediment yields 25 percent less than the 
TABLE 3.-Chemical analyses of water,

[Results in milligrams per

\begin{tabular}{|c|c|c|c|c|c|c|c|c|c|}
\hline Date & 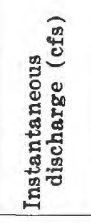 & 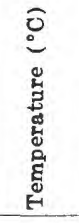 & 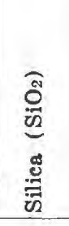 & 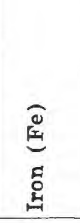 & 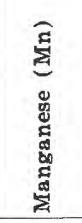 & 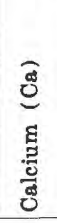 & 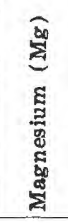 & 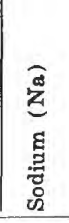 & 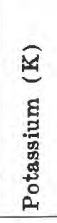 \\
\hline $1-3-57$ & 17 & 1.5 & 6.9 & 0.02 & 0.00 & 29 & 3.4 & 1.1 & 1.1 \\
\hline $10-7-58$ & 3.2 & 7.0 & 7.9 & .02 & .03 & 38 & 7.3 & 1.5 & 1.3 \\
\hline $8-4-59$ & 3.3 & 19.0 & 5.0 & .01 & .00 & 39 & 5.6 & 3.3 & .2 \\
\hline $3-31-60$ & 257 & 10.0 & & .04 & .01 & 16 & 3.3 & 1.9 & 2.3 \\
\hline $4-4-60$ & 162 & 13.0 & 7.5 & .06 & .03 & 15 & 2.8 & 1.2 & 1.9 \\
\hline $7-5-60$ & 8.6 & 17.0 & 7.9 & .07 & .02 & 37 & 6.4 & 3.5 & 1.0 \\
\hline $10-5-60$ & 3.4 & 12.0 & 4.5 & .02 & .01 & 38 & 6.9 & 3.0 & .4 \\
\hline $1-6-61$ & 4.0 & 1.0 & 6.8 & .00 & .00 & 36 & 6.4 & 2.3 & 1.3 \\
\hline $6-14-61$ & 6.0 & 22.0 & 6.9 & .05 & .01 & 37 & 6.0 & 1.5 & 1.2 \\
\hline $11-21-61$ & 3.6 & 8.5 & 5.7 & .04 & .00 & 39 & 6.1 & 2.0 & 1.5 \\
\hline $7-10-62$ & 3.4 & 18.5 & 4.1 & .02 & .00 & 38 & 6.8 & 1.1 & 1.0 \\
\hline $9-25-62$ & 2.8 & 10.0 & 5.5 & .00 & .02 & 39 & 6.3 & 1.4 & 1.5 \\
\hline $10-16-62$ & 3.8 & 19.0 & 4.8 & .01 & .01 & 40 & 7.3 & 1.7 & .8 \\
\hline $1-17-63$ & 15 & 1.5 & 6.5 & .01 & .01 & 24 & 4.4 & 1.0 & .8 \\
\hline $7-11-63$ & 3.0 & 19.0 & 3.8 & .03 & .00 & 34 & 8.3 & 1.6 & 1.2 \\
\hline $10-9-63$ & 2.0 & 13.5 & 5.7 & .01 & .00 & 40 & 7.5 & 2.1 & 1.9 \\
\hline $4-18-64$ & 17 & 15.0 & 4.7 & .02 & .00 & 23 & 3.9 & 2.2 & .2 \\
\hline $8-6-64$ & 3.8 & 20.5 & 5.5 & :02 & .00 & 39 & 7.1 & 2.5 & 1.4 \\
\hline $10-13-64$ & 2.7 & 9.0 & 5.5 & .00 & .00 & 41 & 8.3 & .8 & .5 \\
\hline $12-30-64$ & 13 & 7.0 & 6.2 & .00 & .00 & 28 & 5.8 & 2.8 & 1.2 \\
\hline $2-7-65$ & 680 & 2.0 & 2.7 & .12 & .02 & 10 & 1.0 & 2.6 & 6.5 \\
\hline $4-9-65$ & 20 & 9.0 & 4.7 & .00 & .00 & 22 & 7.8 & 2.3 & 1.5 \\
\hline $8-12-65$ & 2.6 & 18.5 & 5.5 & .01 & .00 & 37 & 6.6 & 1.4 & 1.1 \\
\hline $10-13-66$ & 3.9 & 9.0 & 6.5 & .00 & .00 & 40 & 7.8 & 1.8 & 1.2 \\
\hline $4-21-67$ & 15 & 11.0 & 5.8 & .00 & .00 & 26 & 4.2 & 2.0 & .9 \\
\hline $6-15-67$ & 6.7 & 22.0 & 6.0 & .00 & .00 & 39 & 6.5 & 1.7 & 1.1 \\
\hline $10-24-67$ & 3.9 & 9.0 & 6.4 & & .00 & 40 & 6.5 & 1.9 & 1.8 \\
\hline $5-3-68$ & 8.9 & 13.0 & 4.1 & .07 & .00 & 30 & 6.0 & 2.5 & .8 \\
\hline $10-8-68$ & 4.1 & 12.0 & 1.8 & .12 & .02 & 24 & 6.8 & 2.8 & 1.8 \\
\hline $2-27-69$ & 6.9 & 2.0 & 4.6 & .04 & .02 & 30 & 4.9 & 3.8 & 2.2 \\
\hline $4-5-69$ & 27 & 11.0 & 5.8 & -.. & --- & 24 & 3.9 & 3.4 & 2.6 \\
\hline
\end{tabular}

surrounding area of the Shermans Creek basin. Sediment concentrations observed in the stream were less than $10 \mathrm{mg} / 170$ percent of the time, indicating that streamflow was nearly sediment free most of the time. Silt and clay each make up about 48 percent of the sediment discharge, and sand made up the remainder. The concentration of sand in suspension increases as streamflow increases. At a flow of $900 \mathrm{ft}^{3} / \mathrm{s}\left(25 \mathrm{~m}^{3} / \mathrm{s}\right)$ sand concentrations were approximately $60 \mathrm{mg} / \mathrm{l}$.

The concentration of the chloride ion in water from Bixler Run increased gradually from 1957 to 1969 . Concentrations averaged $2.4 \mathrm{mg} / 1$ from 1957 to 1962 and $4.4 \mathrm{mg} / \mathrm{l}$ from 1963 to 1969 . The 
Bixler Run near Loysville, 1957-6.9

litre, except as indicated ]

\begin{tabular}{|c|c|c|c|c|c|c|c|c|c|c|}
\hline \multirow[b]{2}{*}{ 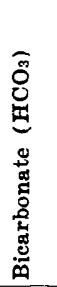 } & \multirow[b]{2}{*}{ 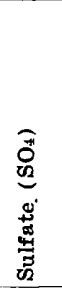 } & \multirow[b]{2}{*}{ 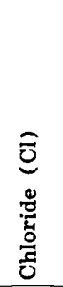 } & \multirow[b]{2}{*}{ 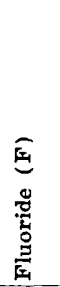 } & \multirow[b]{2}{*}{ 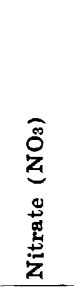 } & \multirow[b]{2}{*}{ 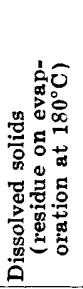 } & \multicolumn{2}{|c|}{$\begin{array}{l}\text { Hardness } \\
\text { as } \mathrm{CaCO}_{3}\end{array}$} & \multirow[b]{2}{*}{ 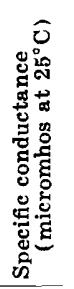 } & \multirow[b]{2}{*}{ 望 } & \multirow[b]{2}{*}{$\frac{0}{8}$} \\
\hline & & & & & & 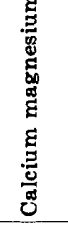 & 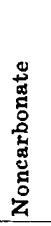 & & & \\
\hline 90 & 12 & 1.6 & 0.0 & 7.1 & 102 & 86 & 12 & 188 & 8.1 & 2 \\
\hline 126 & 18 & 1.9 & .0 & 5.3 & 146 & 125 & 22 & 233 & 7.6 & 5 \\
\hline 126 & 16 & 2.8 & .0 & 4.3 & 150 & 121 & 17 & 241 & 7.5 & 5 \\
\hline 39 & 13 & 1.5 & .2 & 8.7 & 90 & 54 & 22 & 117 & 7.3 & 28 \\
\hline 42 & 12 & 2.4 & .1 & 6.7 & 80 & 49 & 15 & 111 & 7.2 & 20 \\
\hline 124 & 22 & 2.3 & .2 & 7.6 & 145 & 119 & 18 & 228 & 7.7 & 3 \\
\hline 131 & 15 & 2.6 & .1 & 5.9 & 147 & 124 & 16 & 240 & 7.6 & 1 \\
\hline 118 & 15 & 2.6 & .0 & 5.6 & 135 & 117 & 20 & 230 & 7.5 & 3 \\
\hline 121 & 14 & 2.2 & .2 & 6.0 & 139 & 117 & 18 & 230 & 7.8 & 10 \\
\hline 126 & 16 & 2.7 & .1 & 5.6 & 140 & 123 & 19 & 240 & 7.8 & 2 \\
\hline 126 & 15 & 2.6 & .1 & 5.0 & 138 & 123 & 20 & 239 & 7.3 & $\overline{5}$ \\
\hline 125 & 17 & 2.4 & .0 & 8.4 & 151 & 124 & 21 & 260 & 7.6 & 3 \\
\hline 128 & 18 & 4.0 & .1 & 1.9 & 174 & 130 & 25 & 265 & 7.6 & 5 \\
\hline 71 & 12 & 3.2 & .0 & 3.0 & 97 & 78 & 20 & 175 & 7.7 & 5 \\
\hline 130 & 12 & 3.0 & .0 & 5.8 & 147 & 119 & 13 & 246 & 7.4 & 4 \\
\hline 142 & 15 & 2.6 & .0 & 5.6 & 171 & 131 & 15 & 263 & 7.1 & 8 \\
\hline 73 & 14 & 3.2 & .0 & 3.6 & 88 & 74 & 14 & 159 & 7.2 & 8 \\
\hline 133 & 17 & 3.5 & .1 & 6.4 & 144 & 127 & 18 & 260 & 7.6 & 4 \\
\hline 136 & 16 & 2.6 & .1 & 7.6 & 151 & 137 & 25 & 264 & 7.3 & 8 \\
\hline 80 & 19 & 5.8 & .1 & 12 & 126 & 94 & 29 & 208 & 7.5 & 3 \\
\hline 18 & 12 & 5.0 & .1 & 11 & 77 & 29 & 14 & 103 & 6.7 & 50 \\
\hline 72 & 17 & 5.8 & .1 & 6.4 & 103 & 87 & 28 & 175 & 7.2 & 8 \\
\hline 124 & 16 & 3.2 & .1 & 5.2 & 145 & 120 & 18 & 249 & 7.6 & 5 \\
\hline 130 & 21 & $\begin{array}{l}0.4 \\
3.9\end{array}$ & .0 & 5.7 & 174 & 132 & 26 & 265 & 7.6 & 2 \\
\hline 76 & 16 & 43 & .1 & 5.7 & 107 & 82 & 20 & 170 & 7.2 & 3 \\
\hline 122 & 17 & 3.4 & .1 & 7.2 & 148 & 124 & 24 & 237 & 8.0 & 4 \\
\hline 122 & 19 & 4.5 & .1 & 7.8 & 155 & 127 & 27 & 254 & 8.1 & 1 \\
\hline 103 & 16 & 3.7 & .1 & 5.8 & 124 & 100 & 15 & 206 & 7.7 & 3 \\
\hline 86 & 18 & 6.0 & .2 & 5.4 & 131 & 88 & 18 & 189 & 8.1 & 0 \\
\hline 92 & 19 & 8.0 & .2 & 7.2 & 140 & 95 & 20 & 217 & 8.0 & 0 \\
\hline 64 & 20 & 9.0 & .2 & 7.2 & 131 & 76 & 24 & 185 & 7.8 & 1 \\
\hline
\end{tabular}

increase is probably the result of increased use of salts as melting agents.

\section{SELECTED REFERENCES}

Culbertson, J. K., 1957, Progress report of hydrology and sedimentation in Bixler Run, Corey Creek and Elk Run watersheds, Pennsylvanis.: U.S. Geol. Survey open-file rept., $44 \mathrm{p}$.

Dumper, T. As, and Kirkaldie, Louis, 1967, Sediment and erosion estime.tes for Pennsylvania river basins: U.S. Dept. of Agriculture, Soil Conservation Serv., $36 \mathrm{p}$.

Guy, H. P., 1957, The trend of suspended-sediment discharge of the Frandywine Creek at Wilmington, Del., 1947-55: U.S. Geol. Survey open-file rept., p. 1b-12b. 
Johnston, H. E., 1970, Ground-water resources of the Loysville and Mifflintown quadrangles in south-central Pennsylvania: Pennsylvania Geol. Survey 4 th ser. Bull. W-27.

Jones, B. L., 1966, Effects of agricultural conservation practices on the hydrology of Corey Creek basin Pennsylvania, 1954-60: U.S. Geol. Survey Water-Supply Paper 1532-C, 55 p.

Miller, J. R., 1961, Geology and mineral resources of the Loysville quadrangle, Pennsylvania: Pennsylvania Geol. Survey 4th ser. Bull. A-127, 47 p.

Pennsylvania Topographic and Geologic Survey, 1964, Physiographic provinces of Pennsylvania: Pennsylvania Topog. and Geol. Survey map 13.

Reed, L. A., 1971, Hydrology and sedimentation of Corey Creek and Elk Run basins, north-central Pennsylvania: U.S. Geol. Survey Water-Supply Paper 1532-E, $27 \mathrm{p}$.

Searcy, J. K., and Hardison, C. H., 1960, Double-mass curves: U.S. Geol. Survey Water-Supply Paper 1541-B, $66 \mathrm{p}$.

Williams, K. F., and George, J. R., 1968, Preliminary appraisal of stream sedimentation in the Susquehanna River basin: U.S. Geol. s'arvey open-file rept., $73 \mathrm{p}$.

Williams, K. F., and Reed., L. A., 1972, Appraisal of strean sedimentation in The Susquehanna River basin: U.S. Geol. Survey Water-Supply Paper 1532-F, $24 \mathrm{p}$. 